\title{
Methane emissions by dairy cows fed increasing proportions of white clover (Trifolium repens) in pasture
}

\author{
J.M. LEE, S.L. WOODWARD, G.C. WAGHORN and D.A. CLARK \\ Dexcel, PB 3221, Hamilton \\ julia.lee@dexcel.co.nz
}

\begin{abstract}
Methane $\left(\mathrm{CH}_{4}\right)$ production from ruminant digestion has a significant impact on the New Zealand greenhouse gas (GHG) inventory and represents a loss of about $10 \%$ of metabolisable energy (ME) intake. Previous trials with sheep and cattle have demonstrated significantly lower methane losses per unit feed intake from legumes compared to grass dominant pasture. Most trials have compared forages fed as sole diets but white clover (Trifolium repens) is usually fed with perennial ryegrass (Lolium perenne) as a mixed pasture, as it complements ryegrass for animal production. An indoor feeding trial was conducted in December 2003 with thirty-two Holstein-Friesian dairy cows in mid-lactation to determine effects of increasing proportions of white clover on methane emissions and cow performance. Cows were housed indoors and fed perennial ryegrass with $0,15,30$ or $60 \%$ white clover ad libitum on a dry matter (DM) basis. Increasing proportions of white clover resulted in linear increases in dry matter intakes (DMI) and reductions in methane per $\mathrm{kg} \mathrm{DM}$ eaten, although the extent to which $\mathrm{CH}_{4}$ production $/ \mathrm{kg}$ DMI was lowered was less than anticipated from previous measurements from sheep fed white clover as a sole diet. DMI of cows fed $60 \%$ white clover was 20.5 vs. 15.6 $\mathrm{kg} \mathrm{DM} / \mathrm{cow} /$ day for $100 \%$ perennial ryegrass $(\mathrm{P}<0.001)$ with 18.1 vs. $21.7 \mathrm{~g} \mathrm{CH}_{4} / \mathrm{kg} \mathrm{DM}$ for the respective treatments. The increased DMI of cows fed increased levels of white clover resulted in a significant but small increase in total daily $\mathrm{CH}_{4}$ emissions. Milk and milksolids yields also increased from 17.6 to $20.4 \mathrm{~kg} /$ cow/day $(\mathrm{P}<0.001)$ and 1.32 to $1.52 \mathrm{~kg} / \mathrm{cow} /$ day $(\mathrm{P}<0.005)$ respectively as the proportion of white clover increased from 0 to $60 \%$.
\end{abstract}

Keywords: dairy cow, methane emissions, milk production, perennial ryegrass, white clover

\section{Introduction}

Dairy cows grazing perennial ryegrass (Lolium perenne) dominant pasture produce $80-120 \mathrm{~kg}$ methane $\left(\mathrm{CH}_{4}\right)$ per annum, depending on feed intakes and level of production. These losses represent $5-8 \%$ of gross energy (GE) and about $10 \%$ of metabolisable energy (ME) intake (Robertson \& Waghorn 2002; O'Hara et al. 2003). The proportion of energy lost to methane is lower from animals fed legumes compared to grasses (Waghorn et al. 2002) and legumes promote higher intakes and animal production. Harris et al. (1998) showed that increasing white clover (Trifolium repens) content of a pasture diet from $20 \%$ to $50 \%$, increased dry matter intake (DMI) and milksolids (MS) yield of cows by 13 and $32 \%$ respectively.

Methane is derived from hydrogen produced during anaerobic digestion in the rumen and the proportion of feed energy lost is inversely related to dietary fibre concentrations and rate of passage through the rumen (Moe \& Tyrrell 1979; Pinares-Patino et al. 2003). White clover fed as a sole diet has a low rumen retention time compared to ryegrass, related to fibre concentrations which are typically $25-35 \%$ of the dry matter (DM) compared to $40-50 \%$ for ryegrass. When sheep were fed white clover as a sole diet, only $12.5 \mathrm{~g} \mathrm{CH}_{4} / \mathrm{kg}$ DMI was produced (Krause et al. unpublished) which is half that from sheep fed ryegrass-based pasture containing about $30 \%$ white clover (Waghorn et al. 2002).

Several trials have evaluated legumes containing condensed tannins (CT) for milk and methane production by cows in mid- and late-lactation. Woodward et al. (2004) reported a 17\% increase in DMI from cows grazing birdsfoot trefoil (Lotus corniculatus) vs ryegrass pasture, with an $18 \%$ reduction in methane production per unit DMI (19.91 vs $24.15 \mathrm{~g} / \mathrm{kg}$ ). Previously, Woodward et al. (2002) reported a $22 \%$ increase in DMI of cows grazing sulla (Hedysarum coronarium) vs ryegrass pasture (13.1 v. $10.7 \mathrm{~kg} \mathrm{DM} / \mathrm{cow} /$ day) and a $21 \%$ reduction in methane production per unit DMI $(19.5$ v. $24.6 \mathrm{~g} / \mathrm{kg})$. The data suggest a higher level of MS production would be achieved when legumes containing $\mathrm{CT}$ are fed, without a corresponding increase in $\mathrm{CH}_{4}$ emissions.

These previous cow trials demonstrated that legumes fed as a sole diet can reduce methane emissions. Although Waghorn et al. (2002) demonstrated additive effects on methane production when sulla was fed with lucerne (Medicago sativa), this was not the case when chicory (Cichorium intybus) was fed with red clover (Trifolium pratense). The impact of mixed forages on net emissions is not clearly defined, and the suggestion that grains can lower $\mathrm{CH}_{4}$ emissions $(2-2.5 \%$ of $\mathrm{GE})$ seems only to apply to very high (80\%) percentages in the diet (Johnson et al. 2000). The data from grain 
feeding and use of grain in concentrates suggests $\mathrm{CH}_{4}$ production can not be calculated from components of a diet. There is a need to define methane responses to incremental substitution of one feed type with another. Mixed legume-grass pastures form the basis of New Zealand forage feeding and increasing proportions of legumes in the diet of grazing animals could lower net $\mathrm{CH}_{4}$ emissions, as well as improving performance.

White clover is a productive and persistent legume, with well-defined agronomic characteristics, and is a component of most New Zealand pastures. This paper explores the effects of increasing the proportion of white clover in the diet on methane emissions and cow performance of dairy cows fed a base diet of ryegrass during summer.

\section{Materials and methods}

Thirty-two Holstein-Friesian cows were fed ad libitum perennial ryegrass containing $0,15,30$ or $60 \%$ white clover (DM basis) for 11 days. The trial was conducted at Dexcel's Lye Farm, Hamilton, during December 2003. The cows were mid-lactation (144 \pm 12 days in milk) and randomly allocated to four dietary treatments on the basis of current MS yield and live-weight. They were housed in a well-ventilated indoor feeding facility, using Calan gates to obtain intakes from individual cows.

The perennial ryegrass was cv. Bronsyn and the white clover was Grasslands Huia. White clover pastures were sampled on three occasions prior to and during the trial to ensure that nitrate and cyanide concentrations were not toxic. Following some staggers in the adaptation period, the high endophyte ryegrass was changed to the AR1 endophyte selection.

The proportions of ryegrass and white clover were calculated daily on the basis of a rapid (microwave) estimate of feed DM content. Fresh forages were weighed and offered to individual cows at about 0900 and $1700 \mathrm{~h}$ daily to ensure daily refusals were $10-15 \%$ of offered. Refusals were weighed and a visual assessment made of the proportion of white clover at $0700 \mathrm{~h}$ daily.

The trial comprised a 7-day adaptation period followed by a 4-day measurement period when samples of ryegrass and clover pastures were taken each day to determine botanical (hand separation) and chemical composition using near infrared spectroscopy (NIRS). Intakes and milk production were measured throughout the trial and methane emissions were determined during the measurement period. All cows received magnesium chloride and bloat drench (100 ml 1:10 Bloatenz 2in1 (Ecolab Ltd New Zealand)) at morning milkings.

Daily $(\mathrm{pm}+\mathrm{am})$ milk samples collected during the measurement period were analysed to determine fat, crude protein and lactose concentration using a
Milkoscan 133B analyser (Foss Electric, Denmark).

Methane production was measured using the sulphur hexafluoride $\left(\mathrm{SF}_{6}\right)$ tracer technique described by Johnson et al. (1994). Brass permeation tubes were orally placed in the rumen of each cow 45 days prior to the measurement period and released the $\mathrm{SF}_{6}$ marker gas at a known rate (approx. $4.0 \mathrm{mg} /$ day). Respired air was sampled continuously above the nose over four, 24hour periods via a fine bore capillary tube attached to an evacuated yoke strapped to the shoulder of each cow. Background concentrations of atmospheric methane and $\mathrm{SF}_{6}$ were collected from the indoor facility during the trial. Methane and $\mathrm{SF}_{6}$ concentrations were measured by gas chromatography, and the methane emission rate calculated as:

$$
\mathrm{Q}_{\mathrm{CH} 4}=\mathrm{Q}_{\mathrm{SF} 6} \times\left(\left[\mathrm{CH}_{4} \text { yoke }\right]-\left[\mathrm{CH}_{4} \text { background }\right]\right) /
$$
([SF${ }_{6}$ yoke $]-\left[\mathrm{SF}_{6}\right.$ background $]$ )

Where $\mathrm{Q}_{\mathrm{SF} 6}$ is the calibrated rate of permeation from the $\mathrm{SF}_{6}$ capsule.

\section{Statistical analysis}

Milk yield, composition, DMI and methane data were analysed using Residual Maximum Likelihood (REML) procedure with diet clover proportion as a fixed effect and cow as a random effect. For milk yield and composition, pre-trial data were used as a covariate in analysis.

\section{Results and discussion}

The white clover did not contain weeds, grasses or dead matter, whereas the ryegrass pastures comprised $89 \pm$ $2 \%$ ryegrass, $1 \pm 2 \%$ white clover, $2 \pm 1 \%$ other grasses, $2 \pm 1 \%$ weed species and $6 \pm 1 \%$ dead material (DM basis). The ryegrass contained $19 \%$ seedhead and was of moderate quality compared to the white clover (Table 1).

Incremental additions of white clover to ryegrass pasture increased the crude protein $(\mathrm{CP})$ concentration in the diet and reduced the dietary neutral detergent fibre (NDF) for the $60 \%$ clover treatment (Table 1). Cows selected clover from the feed offered (Table 2) and the lower content of clover in refusals, $0,4.3,12.6$ and $48.7 \%$ compared to the $0,15,30$ and $60 \%$ clover offered respectively, suggested a preference for white clover even when it comprised $60 \%$ of the DM on offer.

There were significant increases in daily DMI as the proportion of clover in the diet increased (Table 2; $\mathrm{P}<0.001)$. The increased DMI resulted in a significant but small increase in total daily $\mathrm{CH}_{4}$ emissions, although the loss of energy to methane declined from $10.5 \%$ to $8.6 \%$ of ME or $6.8 \%$ to $5.6 \%$ of GE as the proportion of white clover increased (Table 2; $\mathrm{P}<0.01$ ).

Methane losses expressed on the basis of treatment means (Table 2) suggested a decrease in $\mathrm{CH}_{4} / \mathrm{DMI}$ (g/ 
Table 1 Dry matter (\%), chemical composition (g/100g DM) and metabolisable energy (MJ/kg DM) of the white clover, perennial ryegrass and diets offered to lactating dairy cows.

\begin{tabular}{lccccc}
\hline & White & Perennial & \multicolumn{3}{c}{ Clover content (\% total DM) } \\
\cline { 4 - 6 } clover & ryegrass & 15 & 30 & 60 \\
\hline Dry matter & 14.3 & 19.7 & 18.7 & 17.9 & 16.4 \\
Crude protein & 27.2 & 18.9 & 20.5 & 21.7 & 23.9 \\
Lipid & 4.5 & 4.0 & 4.1 & 4.1 & 4.3 \\
In vitro organic matter digestibility & 83.1 & 77.6 & 78.6 & 79.5 & 80.9 \\
Acid detergent fibre & 20.8 & 25.7 & 24.7 & 24.0 & 22.7 \\
Neutral detergent fibre & 27.6 & 47.8 & 43.9 & 40.9 & 35.5 \\
Soluble carbohydrates & 12.6 & 11.6 & 11.7 & 11.9 & 12.2 \\
Metabolisable energy & 11.8 & 11.1 & 11.2 & 11.3 & 11.5 \\
\hline
\end{tabular}

Table 2 Dry matter intake (DMI), milk yield and methane production of mid-lactation Holstein-Friesian dairy cows fed an increasing proportion of white clover in a perennial ryegrass based diet. Values are the mean for each treatment ( $n=8$ cows) and the standard error of the difference (SED).

\begin{tabular}{|c|c|c|c|c|c|c|}
\hline & \multicolumn{4}{|c|}{- Clover content $(\%$ total DM) - } & \multirow[b]{2}{*}{ SED } & \multirow[b]{2}{*}{$P$ value } \\
\hline & 0 & 15 & 30 & 60 & & \\
\hline DMI (kg/cow/day) & 15.6 & 17.6 & 18.6 & 20.5 & 0.6 & 0.000 \\
\hline Clover content eaten ( $\%$ total DM) & 0 & 19.5 & 34.2 & 61.2 & 1.1 & 0.000 \\
\hline Milk yield (kg/cow/day) & 17.6 & 17.9 & 19.3 & 20.4 & 0.5 & 0.000 \\
\hline Milksolids yield (kg/cow/day) & 1.32 & 1.35 & 1.46 & 1.52 & 0.04 & 0.002 \\
\hline Total methane production $\left(\mathrm{g} \mathrm{CH}_{4} /\right.$ cow/day $)$ & 332.6 & 364.6 & 344.2 & 371.6 & 13.7 & 0.022 \\
\hline Methane per unit intake $\left(\mathrm{g} \mathrm{CH}_{4} / \mathrm{kg} \mathrm{DMI}\right)$ & 21.7 & 20.9 & 18.6 & 18.1 & 1.1 & 0.005 \\
\hline Methane per unit production ( $\left(\mathrm{C} \mathrm{CH}_{4} / \mathrm{kg} \mathrm{MS}\right)$ & 245.6 & 263.5 & 246.9 & 254.7 & 16.5 & 0.601 \\
\hline Methane energy ( $\%$ of gross energy intake) & 6.8 & 6.6 & 5.8 & 5.6 & 0.3 & 0.003 \\
\hline
\end{tabular}

Figure 1 Individual cow methane production per unit feed intake with increasing white clover proportions in the diet. $y=-0.048( \pm 0.0145) x+20.97(P=0.003), r^{2}=0.27$

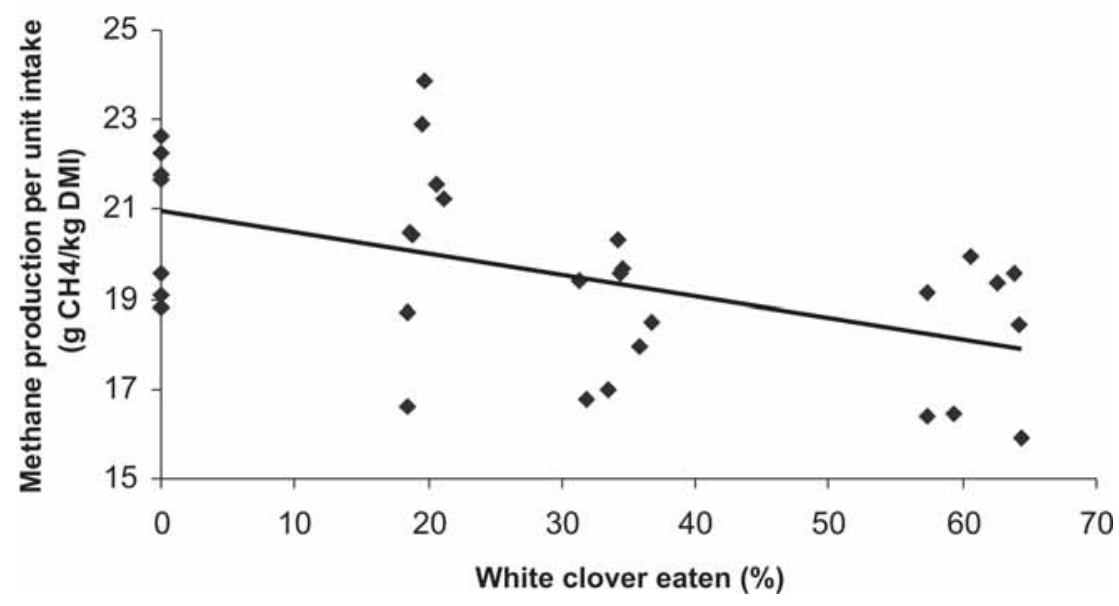

$\mathrm{kg}$ ) with increased percentage of white clover (WC) in the diet: $\mathrm{CH}_{4} / \mathrm{DMI}(\mathrm{g})=-0.063 \mathrm{WC}+21.65 ; \mathrm{R}^{2}=0.88$. Extrapolation to $100 \%$ white clover diet would indicate $\mathrm{CH}_{4}$ emissions of $15.4 \mathrm{~g} \mathrm{CH}_{4} / \mathrm{kg} \mathrm{DMI}$, which is greater than values reported from sheep by Krause (unpublished) of $12.5 \mathrm{~g} \mathrm{CH}_{4} / \mathrm{kg} \mathrm{DMI}$ and lower than values of 19.9 and $19.5 \mathrm{~g} \mathrm{CH}_{4} / \mathrm{kg}$ DMI reported by Woodward et al. $(2002,2004)$ for cows fed birdsfoot trefoil and sulla as sole diets. These data confirm a reduction in $\mathrm{CH}_{4}$ production/ $\mathrm{kg}$ DMI when legumes are fed compared to pasture and also illustrate the risk of making comparisons between trials.

When data for individual cows (Figure 1) were used, the relationship was significant $\left(\mathrm{r}^{2}=0.27, \mathrm{P}=0.003\right)$, in spite of the large differences between individual cows in methane production per unit feed eaten, especially for 
the $15 \%$ clover treatment. Individual cow data also showed a poor relationship between $\mathrm{g} \mathrm{CH}_{4} / \mathrm{kg} \mathrm{DMI}$ and NDF intake $\left(r^{2}=0.29\right)$.

Variations between individual cows are common in most studies and can persist over time (Robertson \& Waghorn 2002). Variation will provide opportunities to select animals for reduced methane production but an understanding of the physiological basis for differences between individuals may facilitate selection.

The concentration of fibre and non-fibre carbohydrates is able to explain up to $67 \%$ of variation in $\mathrm{CH}_{4}$ emissions attributable to diet (Wilkerson et al. 1995). Very low methane emissions have only been obtained with birdsfoot trefoil fed as a sole diet (Waghorn et al. 2002), white clover as a sole diet (Krause et al. unpublished) and over $80 \%$ grain in a diet (Johnson et al. 2000). Mixtures of either grains with roughages or white clover with pasture in this study result in higher methane emissions than predicted on the basis of single component values.

Increasing proportions of white clover in the diet increased milk $(\mathrm{P}<0.001)$ and MS yields (Table 2, $\mathrm{P}<0.01$ ) but the responses were only about $40 \%$ of that anticipated from increased ME intakes and nutritive value. Similar trials have shown that increasing white clover content from $20 \%$ to $50 \%$ in a ryegrass-white clover diet increased milk yield by $30 \%$ (Harris et al. 1997a, b; Harris et al. 1998). However, a greater response in MS production would be expected when poorer quality ryegrass is fed. The short duration of this trial prevented a meaningful assessment of treatment upon liveweight change.

\section{Conclusion}

This trial demonstrates that increasing the percentage of white clover fed with pasture will decrease both the $\mathrm{CH}_{4}$ emissions $/ \mathrm{kg}$ DMI and as a percentage of gross energy intake (GEI). The increased DMI of cows fed increased levels of white clover in their diet resulted in a significant but small increase in total daily $\mathrm{CH}_{4}$ production. In other words, increasing white clover content in the diet was not effective in reducing total $\mathrm{CH}_{4}$ emissions per cow. The response in MS yield reported here resulted in diets having a similar rate of $\mathrm{CH}_{4}$ production/kg MS across all diets.

\section{Practical implications}

This trial was conducted as part of a wider programme designed to examine the effect of different diets on $\mathrm{CH}_{4}$ production from dairy cows. Although the capacity of legumes to reduce $\mathrm{CH}_{4}$ production/kg DMI has been confirmed, the potential benefits of including legumes, such as white clover, in the diet must now be assessed at the whole farm systems level. This will ensure that the impacts of increasing legume content, not only on production and environmental sustainability, but also total DM production can be evaluated.

\section{ACKNOWLEDGEMENTS}

The authors acknowledge the assistance of Dexcel technical staff: G. Ferguson, R. Jensen, E. Minneé, D. Porter, P. Roberts, S. Van Vugt, D. Waugh and AgResearch staff: A. Cavanagh, H. Clark and G. Molano, the statistical expertise of B. Dow and all the help afforded by Lye dairy staff. This work was funded by Dairy InSight and the Ministry of Agriculture and Forestry.

\section{REFERENCES}

Harris, S.L.; Auldist, M.J.; Clark, D.A.; Jansen, E.B.L. 1998. Effect of white clover content in the diet on herbage intake, milk production and milk composition of New Zealand dairy cows housed indoors. Journal of Dairy Research 65: 389-400.

Harris, S.L.; Clark, D.A.; Auldist, M.J.; Waugh, C.D.; Laboyrie, P.G. 1997a. Optimum white clover content for dairy pastures. Proceedings of the New Zealand Grassland Association 59: 29-33.

Harris, S.L.; Clark, D.A.; Jansen, E.B.L. 1997b. Optimum white clover content for milk production. Proceedings of the New Zealand Society of Animal Production 57: 169-171.

Johnson, K.A.; Huyler, M.T.; Westburg, H.H.; Lamb, B.R.; Zimmerman, P. 1994. Measurement of methane emissions from ruminant livestock using a $\mathrm{SF}_{6}$ tracer technique. Environmental Science and Technology 28: 359-362.

Johnson, D.E.; Johnson, K.A.; Ward, G.M; Branine, M.E. 2000. Chapter 8. Ruminants and other animals. pp. 112 -133. In: Atmosphere methane. It's role in the global environment. Ed. Khalil, M.A.K. SpringerVerlag, Berlin, Germany.

Moe, P.W; Tyrrell, H.F. 1979. Methane production in dairy cows. Journal of Dairy Science 62: 1583-1586.

O'Hara, P.; Freney, J.; Ulyatt, M. 2003. Abatement of agricultural non-carbon dioxide greenhouse gas emissions. A study of research requirements. Ministry of Agriculture and Forestry, Wellington. www.maf.govt.nz/publications.

Pinares-Patino, C.S.; Ulyatt, M.J.; Lassey, K.R.; Barry, T.N.; Holmes, C.W. 2003. Rumen function and digestion parameters associated with differences between sheep in methane emissions when fed chaffed lucerne hay. Journal of Agricultural Science 140: 205-214.

Robertson, L.J.; Waghorn, G.C. 2002. Dairy industry perspectives on methane emissions and production from cattle fed pasture or total mixed rations in New 
Zealand. Proceedings of the New Zealand Society of Animal Production 62: 213-218.

Waghorn, G.C.; Tavendale, M.H.; Woodfield, D.R. 2002. Methanogenesis from forages fed to sheep. Proceedings of the New Zealand Grassland Association 64: 167-171.

Wilkerson, V.A.; Casper, D.P; Mertens, D.R. 1995. The prediction of methane production of Holstein cows by several equations. Journal of Dairy Science 78: 24022414.
Woodward, S.L.; Waghorn, G.C.; Lassey, K.R.; Laboyrie, P.G. 2002. Does feeding sulla (Hedysarum coronarium) reduce methane emissions from dairy cows? Proceedings of the New Zealand Society of Animal Production 62: 227-230.

Woodward, S.L.; Waghorn, G.C.; Laboyrie, P.G. 2004. Condensed tannins in birdsfoot trefoil (Lotus corniculatus) reduce methane emissions from dairy cows. Proceedings of the New Zealand Society of Animal Production 64: 160-164. 
